Jpn. J. Oral Biol., $32: 209-225,1990$.

原著

\title{
電気性味覚の発現機序に関与する
}

\author{
$\mathrm{Na}^{+}$チャネルについて
}

水 越 常 善

朝日大学菌学部口腔生理学講座（指学：船越正也教授）

〔受付 : 平成元年10月11日〕

\section{Sodium channels participate in the transduction mechanism for "electric taste"}

\author{
Tsuneyoshi Mizukoshi \\ Department of Oral Pysiology, Asahi University School of Dentistry \\ Hozumi, Motosu, Gifu 501-02, Japan \\ (Director: Masaya Funakoshi) \\ [Accepted for publication: Octcber 11, 1989]
}

Key words : Electric taste/ taste transduction mechanism/sodium channel

\begin{abstract}
Taste transduction mechanisms for " electric taste" were studied by examining effects of lingual treatment with the sodium channel blockers (amiloride, procaine and tetrodotoxin $<\mathrm{TTX}>$ ) on the rat chorda tympani nerve responses to chemical and electrical (anodal) stimulations of tongue.

The lingual treatment of amiloride produced ion-specific inhibition of integrated responses of the whole chorda tympani nerve to both chemical stimulation with $0.1 \mathrm{M} \mathrm{NaCl}$ and electrical stimulation with $0.001 \mathrm{M} \mathrm{NaCl}$ as the bathing medium. Procaine and TTX also suppressed responses to electrical stimulations with $0.001 \mathrm{M} \mathrm{NaCl}$, but these drugs produced almost no effect on responses to chemical stimuli alone.

Similar ion-specific and/or stimulus-specific inhibitions of amiloride and/or TTX were observed also in responses of single chorda tympani nerve fibers, although the extent of the inhibition of the responses by each drug varied among the fibers.

These results suggest that the taste transduction for " electric taste" involves at least three different mechanisms, the first is through a amiloride-sensitive sodium channel, the second through a TTX-sensitive sodium channel, and a third route, not through the amiloride-and TTX-sensitive channels.
\end{abstract}

\section{緒言}

舌に弱い電流を流すといわゆる “電気性味覚” が誘発される1”。一般に，陽極を舌表面に陰極を 他部におき直流電気刺激すると,酸味が感じられ，

（广501-02）岐阜県本㢼郡穂皘町穂皘1851-1
反対に陰極を舌表面におき直流刺激すると，弱い 甘苦い味がすることが知られている2’。

この電気性味覚は, 日常我々が感じる味覚とは 少し異なるが, 塩, 酸, 糖溶液などによる化学性 味覚と比べると，舌の刺激部位をより正確に限定 でき，閾值の測定も容易である利点があり，電気 刺激装置があれば簡単に測定することができるこ 
とから臨床味覚検査によく用いられている。特に， 口蓋, 内耳周辺の外科手術の際に起こり得る末梢 味神経の損賃の検査，あるいは味覚障害の検査な どに最も簡便で再現性の高い方法として有用とな

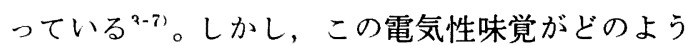
なメカニズムで発現するのかについては，現在な お不明の点が多い。

ヒトの官能テストやラット，八ムスター，カエ ルなどを用いた神経生理学的実験結果から，その 発現機序については大きく 3 つの考え方が提唱さ れている。第 1 は, 電流が直接味神経に流れ, 神 経を興奮させるとするもの ${ }^{21}$ ，第2は，電気刺激に より舌表面のイオンが電気泳動的に受動膜側に移 動し, 味覚受容器を刺激して味細胞を興窝させる とするもの ${ }^{2,8-10)}$ 。第3は, 電流が受容膜を介して 味細胞のシナプス部位に流れその部位の細胞膜を 脱分極させ， シ十プス伝達が起こるとするもの ${ }^{11}$ である。

第 1 の説は, 電気性味覚の発現は味受容膜を介 さないとするもので，化学刺激による味覚の発現 機序とはかなり異なっている。第 2 , 第 3 の説は 化学刺激と電気刺激の両種による味覚の 発現機序 が類似しているとするもので, 特に味覚の受容,

トランスダクションメカニズムが一部あるいは全 部共通するとする考え方である。陽極刺激に対す るラット，八ムスター，カエルなどの味神経応答 を調べると，電気刺激の際に用いるメディウムの イオン種によって応答の大きさが異なり，そのイ オン応答特性は化学刺激の場合とほぼ一致するこ となどから第 2 ，第 3 の説を支持する報告は多

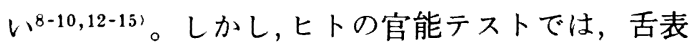
面のイオン種を種々変化させても陽極刺激で誘発 される味覚は酸味であり，イオン特異性は不明確 であること ${ }^{12)}$ ，またラット単一鼓索神経線維の中 には，化学刺激に対する応答と電気刺激に対する 応答のイオン特異性が 全く異なるものも見出され ていること年13,14)などから，電気性味覚の発現機 序は化学性味覚の発現機序と一部異なっている可 能性が考えられる。

近年, 種々の動物の味細胞で, アミロライド感

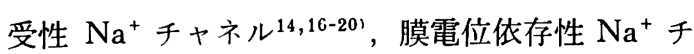
ヤネル22-23)，膜電位依存性 $\mathrm{Ca}^{2+}$ チャネル20)など
のイオンチャネルの存在が報告され，それらチャ ネルが味応答発現に関与している可能性が示唆さ れている。そこで本研究は, 電気性味覚の発現機 序を明らかにする目的で, 化学・電気両種刺激に よるラット鼓索神経応答に対するアミロライド感 受性及び膜電位依存性 $\mathrm{Na}^{+}$チャネルの阻害剂の 効果を比較検討した。

\section{実験方法}

実験には，30 匹の雄のウィスター系のラット （300～500g）を用いた。ネンブタール麻酔 $(50 \mathrm{mg} /$ $\mathrm{kg}$ ）下で，気管カニューレを装着し，頭部を固定 後, 鼓索神経を露出した。神経は露出後周囲組織 より分離し，中枢側で切断した。味応答は主とし て鼓索相経全線維束より記録したが, 必要に応じ て単一神経線維からも記録した。記録電極には,

銀・塩化銀電極を用い，それに鼓索神経をのせ不 関電極は手術部位の近くに置いた。化学および電 気刺激に対する神経応答は, 増幅器（医用電子光 学K-1）を介し，オシロスコープ（日本光電 VC10）上でモニターした。鼓索神経全線維束の応答 は積分計（バイドラー型）にて積分し，単一神経 線維の応答は直接サーマルアレイコーダ（日本光 電) またはデータレコーダー(ソニーDFR-3515) に記録した。ラット舌の舌尖側半分をシリコン製 のフローチャンバーで覆った。各溶液は, “Tasto-matic ",24) でコントロールされた電磁弁で切り 換え, フローチャンバーを介し，一定時間舌表面 に一定の流速 $(2.5 \mathrm{~m} l / \mathrm{sec})^{9)}$ で流した。

電気刺激は陽極電気刺激とし, 陽極の銀・塩化 銀電極をフローチャンバーの内壁に設置し，陰極 の銀・塩化銀電極は頸部皮下に装着した。舌への 電気刺激には，Trapezoid Generator（ダイヤメ ディカル）を用いた。電流值を安定させるため刺 激装置と刺激電極との間に $1 \mathrm{M} \Omega$ の抵抗を直列に つないだ。ピーク電流值は $2.5 \sim 30 \mu \mathrm{A}$ で, 立ち上 がり速度は $100 \mu \mathrm{A} / \mathrm{sec}$, 刺激時間は約 10 秒で行っ た。電流值は，電流計でモニターした。

化学刺激に用いた標準味溶液は, $0.1 \mathrm{M} \mathrm{NaCl}$, (必要に応じて $0.001 \sim 1.0 \mathrm{M}$ ), $0.1 \mathrm{M} \mathrm{KCl}$ (必 要に応じて $0.001 \sim 1.0 \mathrm{M}), 0.1 \mathrm{M} \mathrm{HCl}, 0.1 \mathrm{M}$

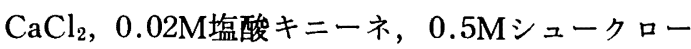



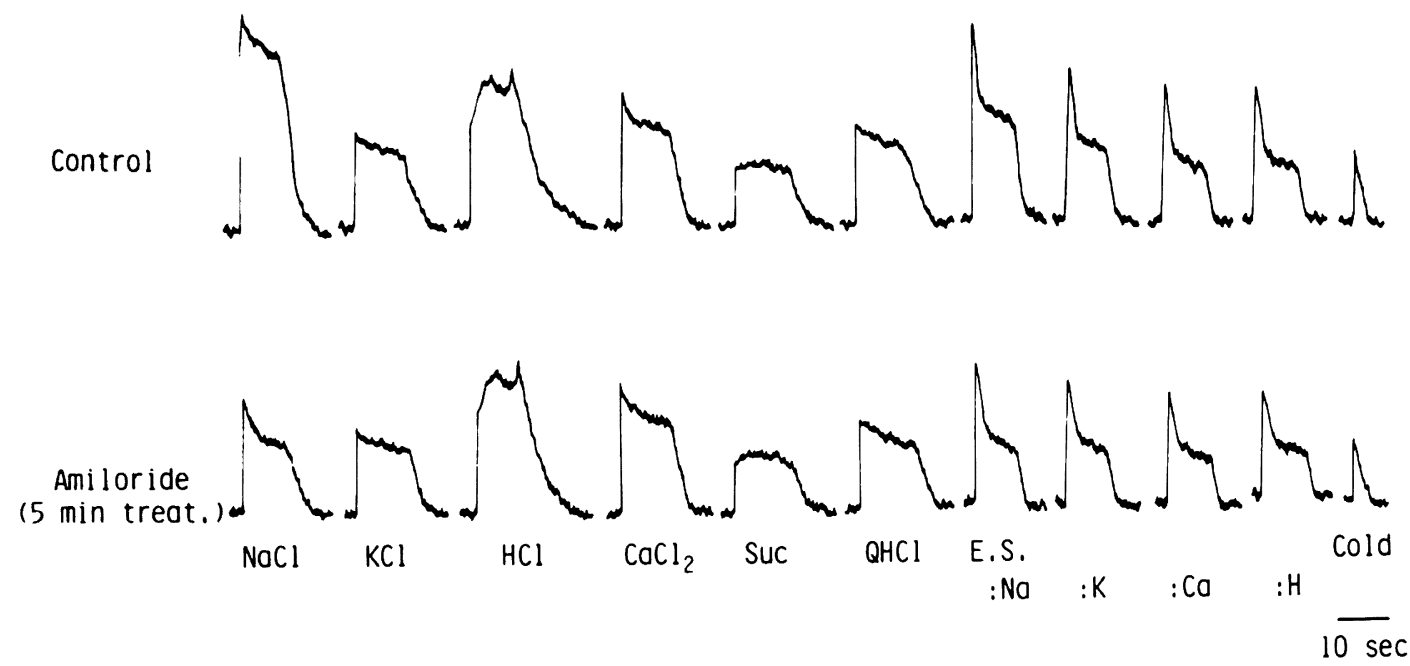

Fig. 1 Integrated chorda tympani responses of a rat to six taste stimuli $(0.1 \mathrm{MNaCl}, 0.1 \mathrm{MKCl}$, $0.01 \mathrm{M} \mathrm{HCl}, 0.1 \mathrm{M} \mathrm{CaCl}_{2}, 0.5 \mathrm{M}$ sucrose, $0.02 \mathrm{M}$ quinine $-\mathrm{HCl}$ ), and the anodal current stimulation $(15 \mathrm{uA})$ with the four bathing medium $(0.001 \mathrm{M} \mathrm{NaCl}, 0.001 \mathrm{M} \mathrm{KCl}, 0.001 \mathrm{M} \mathrm{CaCl}$, $0.0001 \mathrm{M} \mathrm{HCl}$ ), and cold stimulation with $5^{\circ} \mathrm{C}$ distilled water before (control) and after (amiloride) $100 \mu \mathrm{M}$ amiloride treatment applied to the tongue for $5 \mathrm{~min}$.

スで約 $20^{\circ} \mathrm{C}$ の蒸留水で調整した。冷刺激として, 約 $5^{\circ} \mathrm{C}$ の蒸留水を用いた。電気刺激のメディウム は, $1 \mathrm{mM} \mathrm{NaCl}, 1 \mathrm{mM} \mathrm{HCl}, 1 \mathrm{mM} \mathrm{KCl}, 1$ $\mathrm{mM} \mathrm{CaCl}_{2}$ を用いた。舌の洗浄は蒸留水を用い， 洗浄時間は 1 分間以上とした ${ }^{25)}$ 。電気刺激に用い たメディウムは，刺激前30秒間と刺激期間中流し 続けた。

用いた薬物は， $0.1 〜 1.0 \%$ プロカイン $(10,30$ 分間), $100 \mu \mathrm{M}$ アミロライド (2.5分間), $1 \mu \mathrm{M}$ テトロドキシン (10分間) を用い，カッコ内の時 間で舌処理した。

鼓索神経全線維束の積分応答值は，記録紙上よ り計測し, 各刺激に対する応答值は, tonic 応答 の刺激 5 秒後の值とした。鼓索神経単一神経線維 の応答值は, 各刺激開始後 5 秒間のインパルス数 とした。

\section{実験 結 果}

I .アミロライド舌処理による応答抑制効果

種々の上皮細胞の受動的 $\mathrm{Na}^{+}$輸送を抑制する 薬物として知られているアミロライド16-19)で舌を 処理し, 化学電気両種刺激に対する応答の抑制効 果について検討した。

Fig. 1 は， $100 \mu \mathrm{M}$ アミロライド舌処理前のコ
ントロールと 5 分間舌処理後の 各刺激に対する鼓 索神経全線維束の積分応答例を，Fig. 2 はそれ ぞれコントロールを 100 とした時のアミロライド 舌処理後の相対応答值（\%）を示す。

まずコントロールの化学刺激に対する積分応答 は標準味溶液として今回用いた濃度で比較する と, $\mathrm{NaCl}$ が最も大きく, 次いで $\mathrm{HCl}, \mathrm{CaCl}_{2}$, 塩 酸キニーネ, $\mathrm{KCl}$, シュークロースの順であった。 それに対して電気刺激(陽極 $15 \mu \mathrm{A}$ ) の各メディウ ムを用いた時の応答の大きさは， $\mathrm{NaCl}>\mathrm{KCl}>$ $\mathrm{CaCl}_{2} \geqq \mathrm{HCl}$ の順であった。アミロライド舌処理 後, 化学刺激では $\mathrm{NaCl}$ に対する応答だけがコ ントロールの約 $50 \%$ （刺激 5 秒後の応答值）に減 少し, 統計的に有意な抑制が認められた (t-test, $\mathrm{p}$ $<0.05)$ 。電気刺激では $\mathrm{NaCl} と \mathrm{KCl}$ をメディ ウム $(\mathrm{Na}$ メディウム，Kメディウム $)$ として用 いた時の応答が,それぞれコントロールの約 $70 \%$ ， $80 \%$ に減少したが， Na メディウムの場合のみが 統計的に有意であった（t-test， $\mathrm{p}<0.05) 。$

化学劇激の $\mathrm{NaCl}, \mathrm{KCl}$ のアミロライド舌処理 前後の濃度応答曲線（Fig. 3) を比較すると, 0.3 $\mathrm{M}$ 以上の $\mathrm{KCl}$ の応答はアミロライドで抑制され る傾向が認められ，イオン特異性が高濃度領域で 減少することが示唆された。 


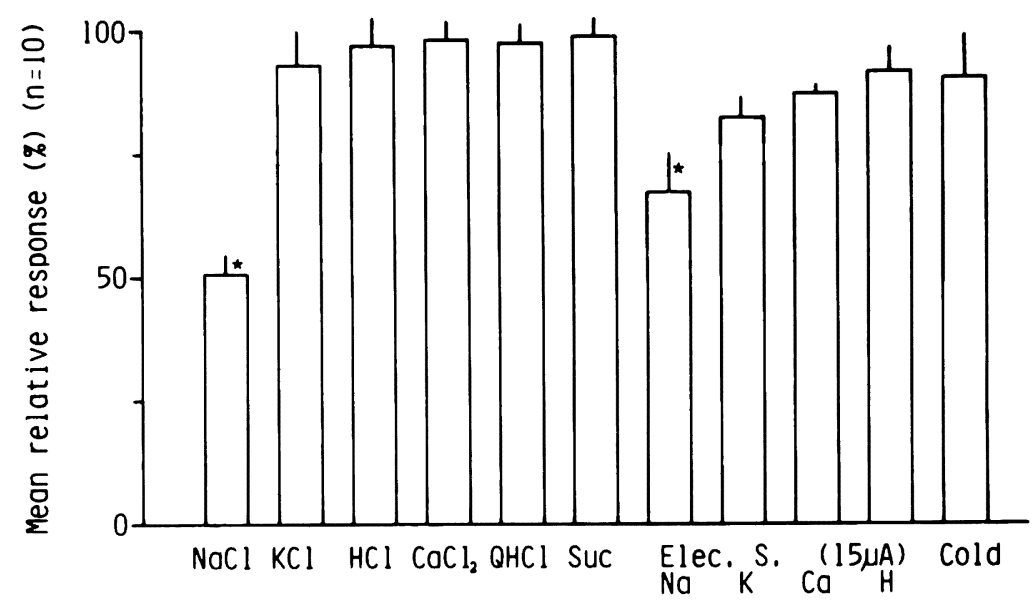

Fig. 2 Mean percent responses (control $=100 \%$ ) of the chorda tympani nerve to chemical, electrical and cold stimulations after the amiloride treatment for $5 \mathrm{~min}$. Vertical bears indicate SDs.

$\star$ : $\mathrm{t}$-test, $\mathrm{p}<0.05$.

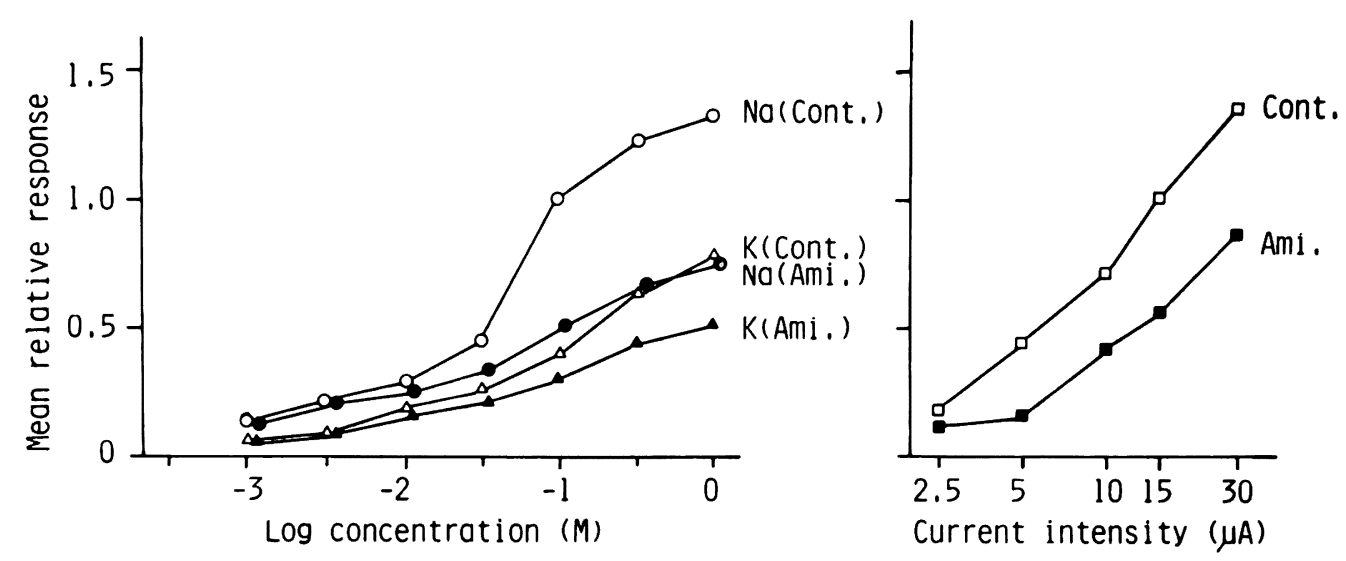

Fig. 3 Concentration-response relationship for $\mathrm{NaCl}$ (circles) and $\mathrm{KCl}$ (triangles) when the response magnitude for $0.1 \mathrm{M} \mathrm{NaCl}$ was taken as unity (1.0) (left) and intensity-response relationship for the anodal current stimulation with $0.001 \mathrm{M} \mathrm{NaCl}$ in the bathing medium when the response magnitude for $15 \mu \mathrm{A}$ was taken as unity (1.0) (right) before (open symbols) and after (closed symbols) the amiloride treatment.

II .プロカイン舌処理による応答抑制効果

膜電位依存性 $\mathrm{Na}^{+}$チャネルの阻害剂として知 られる局所麻酔薬のプロカイン 26-29) 舌処理による 電気化学両種刺激に対する応答の抑制効果の選択 性について調べた。

Fig. 4 は1\%塩酸プロカインで10分間舌処理し た時の鼓索神経全線維杏の各刺激に対する積分応 答例を示し，Fig. 5 は処理前の応答に対する処理 後の各刺激の相対応答值（\%）を示す。プロカイ ン10分間舌処理では, 電気刺激に対する応答だけ
が顕著に抑制され，10例の平均值でコントロール の $43.8 \%$ のレベルまで応答は減少した（t-test， p $<0.05)$ 。それに対し,プロカイン30分間舌処理の 場合, 電気刺激に対する応答だけでなく $0.02 \mathrm{M}$ 塩

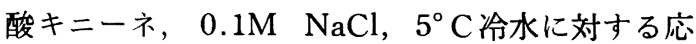
答もそれぞれ有意に抑制された (t-test， p<0.05)。 Fig. 6 は $1 \%$ プロカイン 10 分間舌処理前後の化学 刺激の $\mathrm{NaCl}$ の濃度応答曲線と $\mathrm{Na}$ メディウム での電気刺激の強度応答曲線を示す。化学刺激の $\mathrm{NaCl}$ 応答は，0.001〜 1.0Mの濃度範囲において 

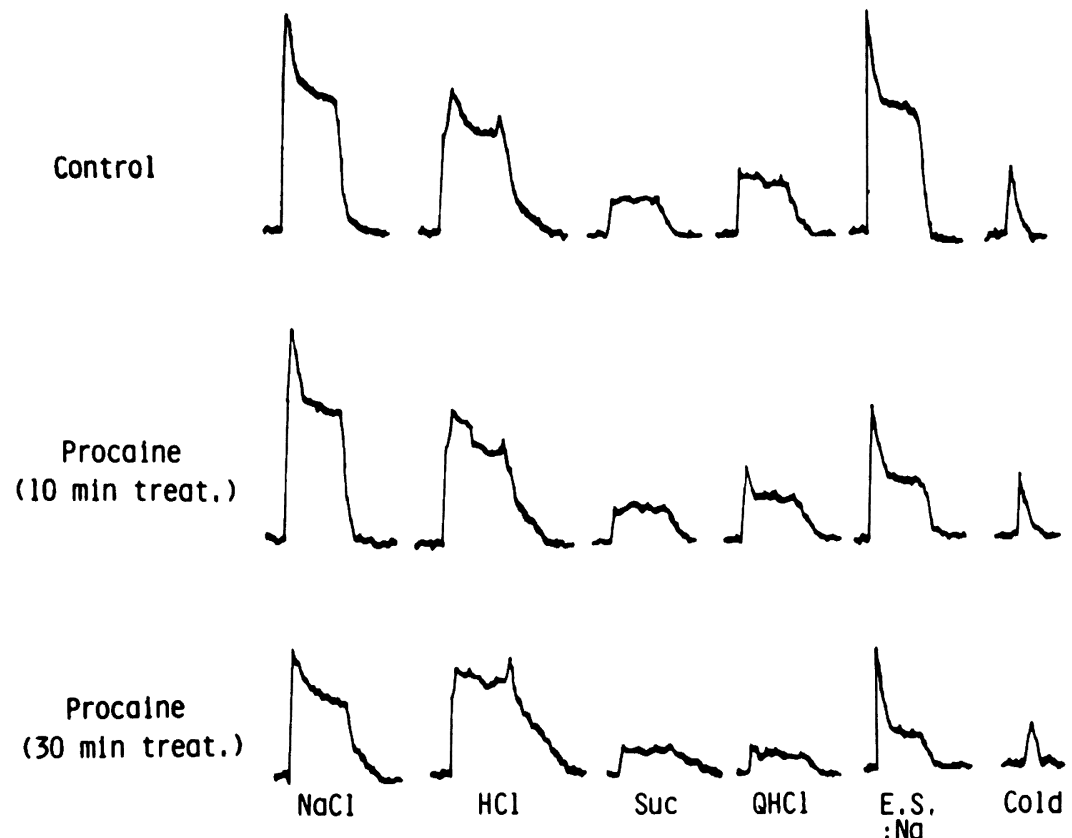

$\overline{10} \mathrm{sec}$

Fig. 4 Integrated chorda tympani responses of a rat to four taste stimuli $(0.1 \mathrm{M} \mathrm{NaCl}, 0.1 \mathrm{M} \mathrm{HCl}$, $0.5 \mathrm{M}$ sucrose, $0.02 \mathrm{M}$ quinine $-\mathrm{HCl}$ ) and the anodal current stimulation with $0.001 \mathrm{M} \mathrm{NaCl}$ in the bathing medium (at $15 \mu \mathrm{A}$ ) and cold stimulation with $5^{\circ} \mathrm{C}$ distilled water before (control) and after 10 minutes treatment $(10 \mathrm{~min}$. treat.) and 30 minutes treatment $(30 \mathrm{~min}$. treat.) of $1 \%$ procaine applied to the tongue.

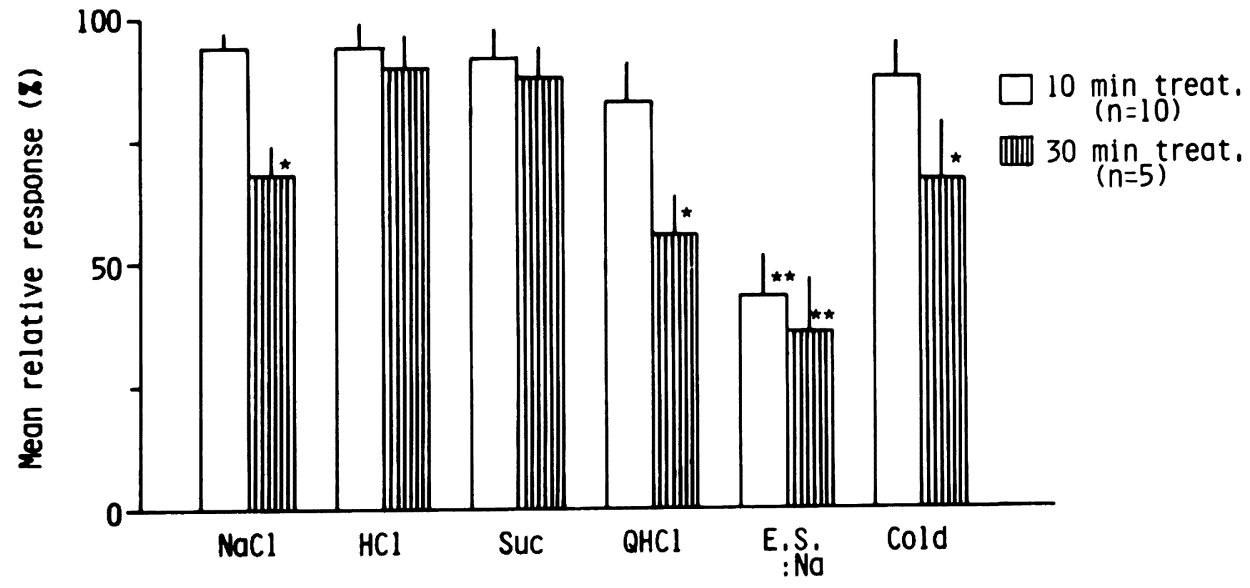

Fig. 5 Mean percent responses (control $=100 \%$ ) of the chorda tympani nerve to chemical, electrical and cold stimulations after $1 \%$ procaine treatment for $10 \mathrm{~min}$ (open columus) and $30 \mathrm{~min}$ (striped columns). Vertical bars indicate SDs.

$\star$ : t-test, $\mathrm{p}<0.05 ; \star \star: \mathrm{p}<0.01$. 


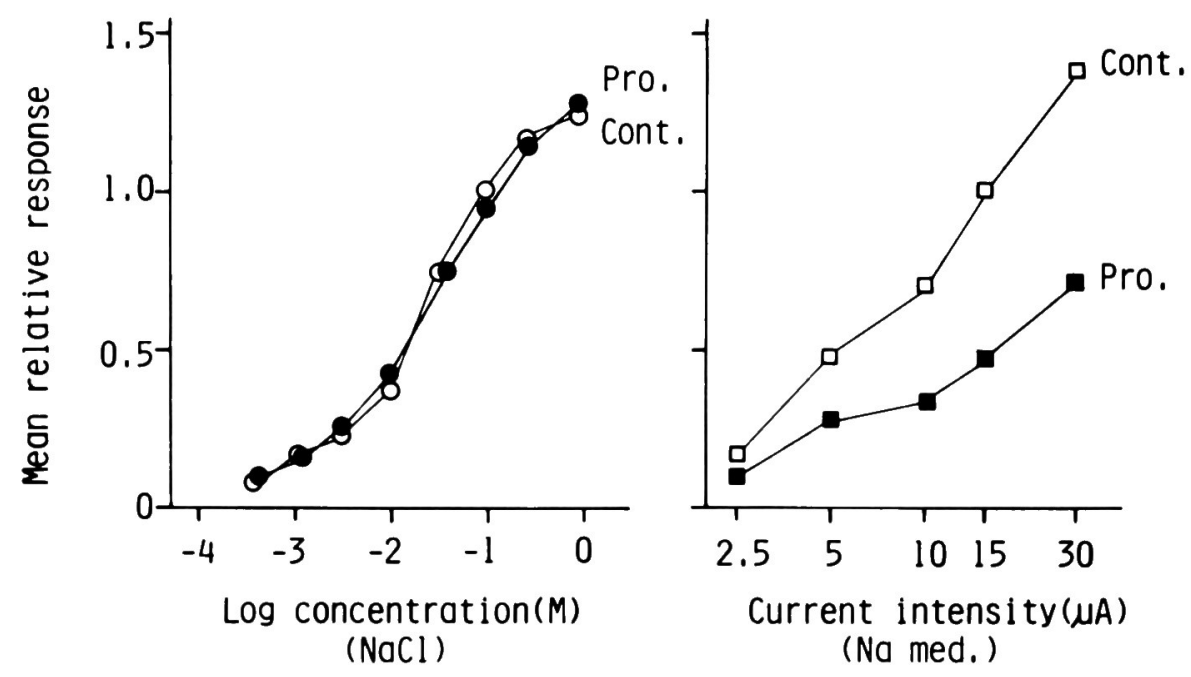

Fig. 6 Concentration-response relationship for $\mathrm{NaCl}$ when the response magnitude for $0.1 \mathrm{M}$ was taken as unity (1.0) (left) and intensity-response relationships for the anodal current stimulation with $0.001 \mathrm{M} \mathrm{NaCl}$ in the bathing medium when the response magnitude for $15 \mu \mathrm{A}$ was taken as unity (1.0) (right) before (open symbols) and after (closed symbols) the lingual treatment of $1 \%$ procaine for $10 \mathrm{~min}$.

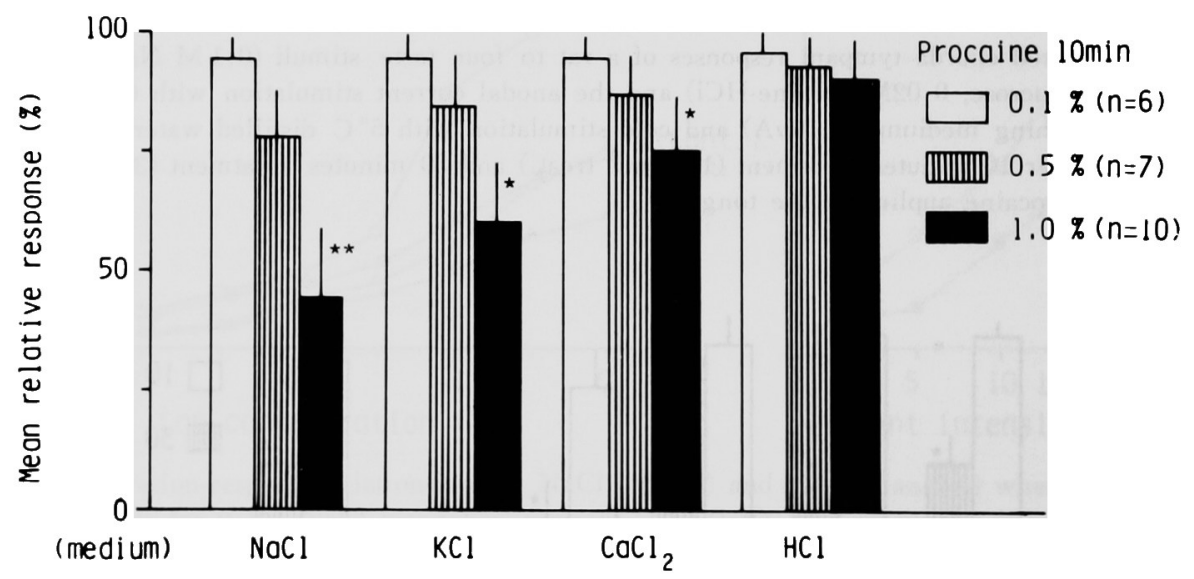

Fig. 7 Mean percent responses (control $=100 \%$ ) of the chorda tympani nerve to anodal current stimulations with $0.001 \mathrm{M} \mathrm{NaCl}, 0.001 \mathrm{M} \mathrm{KCl}, 0.001 \mathrm{M} \mathrm{CaCl}_{2}, 0.0001 \mathrm{M} \mathrm{HCl}$ in the bathing medium after the lingual treatment of $0.1,0.5$ and $1.0 \%$ procaine for $10 \mathrm{~min}$. A figure in each parenthesis shows the number of animals used in each experiment. Vertical bars indicate SDs.

$\star$ : t-test, $\mathrm{p}<0.05, \star \star: \mathrm{p}<0.01$.

変化が認められなかったが, 電気刺激の 応答は2.5 $\sim 30 \mu \mathrm{A}$ の範囲でそれぞれコントロールの 40〜60 \%レベルに減少し応答抑制効果が認められた。

応答抑制効果の選択性が 高かった10分間舌処理 における電気刺激のメディウムとプロカインの濃 度を変えた時の応答の抑制効果の大きさを比較し た。Fig. 7 に示すようにコントロールに対する

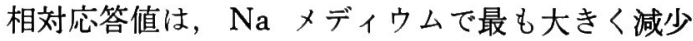
し, 次いでKメディウム, $\mathrm{Ca}$ メディウム, $\mathrm{H}$ メ ディウムの順であり，減少の大きさは処理したプ ロカイン裖度に依存していた。応答の減少が統計 的に有意であったのは, $1.0 \%$ プロカイン舌処理後 の $\mathrm{Na}, \mathrm{K}, \mathrm{Ca}$ の各メディウムでの電気刺激の 場合だけであった（t-test, $\mathrm{p}<0.05) 。$ 


\section{Control}
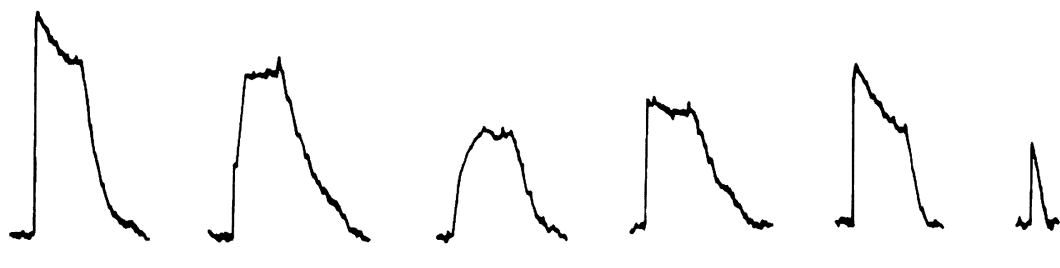

TTX (10 min treat.)
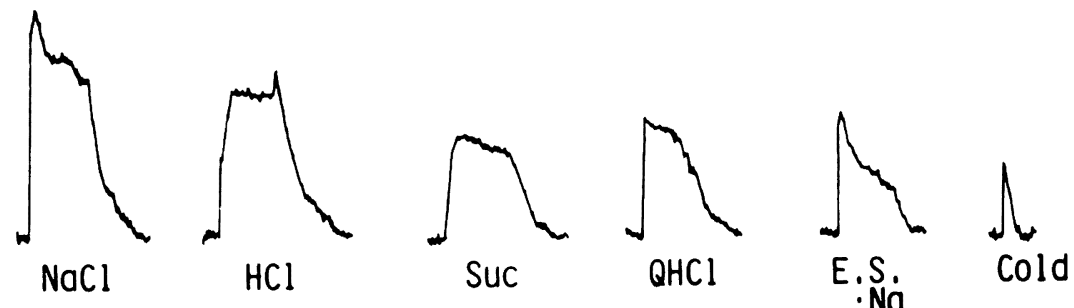

$10 \mathrm{sec}$

Fig. 8 Integrated chorda tympani responses of a rat to the four taste stimuli $(0.1 \mathrm{M} \mathrm{NaCl}, 0.01 \mathrm{M}$ $\mathrm{HCl}, 0.5 \mathrm{M}$ sucrose, $0.02 \mathrm{M}$ quinnine $-\mathrm{HCl}$ ) and the anodal stimulation with $0.001 \mathrm{M} \mathrm{NaCl}$ in the bathing medium (at $15 \mu \mathrm{A}$ ) and cold stimulation with $5^{\circ} \mathrm{C}$ distilled wated before (Control) and after (TTX) the treatment of $1 \mu \mathrm{M}$ TTX applied to the tongue for $10 \mathrm{~min}$.

III. テトロドトキシン (TTX) 舌処理による応 答抑制効果

電気刺激に対する応答を選択的に抑制したプロ カインは, 膜電位依存性 $\mathrm{Na}^{+}$チャネルの阻害剂 であるが，その $\mathrm{Na}^{+}$イオンに対する選択性は厳 密なものではないとされている。そこで本実験で は, より特異的な $\mathrm{Na}^{+}$チャネル阻害荗として知 られているテトロドトキシン22,29'舌処理による応 答抑制効果について検討した。

Fig. 8 は $1 \mu \mathrm{M}$ TTX 10 分間舌処理前後の鼓 索神経全線維束の各刺激に対する積分応答を,

Fig. 9 は処理前の応答に対する処理後の各刺激 の相対応答值を示す。応答の変化は，1\%プロカ イン10分間舌処理のときと極めて類似しており, $1 \mu \mathrm{M}$ TTX 10分間処理により電気刺激に対する 応答のみが コントロールの約 $65 \%$ まで減少した。 この応答の減少は 統計的に有意であった（t-test, $\mathrm{p}<0.05)$ 。また応答は舌洗浄開始後約15分でほぼ コントロールレベルまで回復し, プロカイン舌処 理の場合と比へ，応答の抑制効果も若干弱く（プ ロカイン10分処理の場合, コントロールの約 44\%） 応答の回復時間も早い（プロカイン10分処理で 30 分）ことが分かった。電気刺激に対する応答抑制

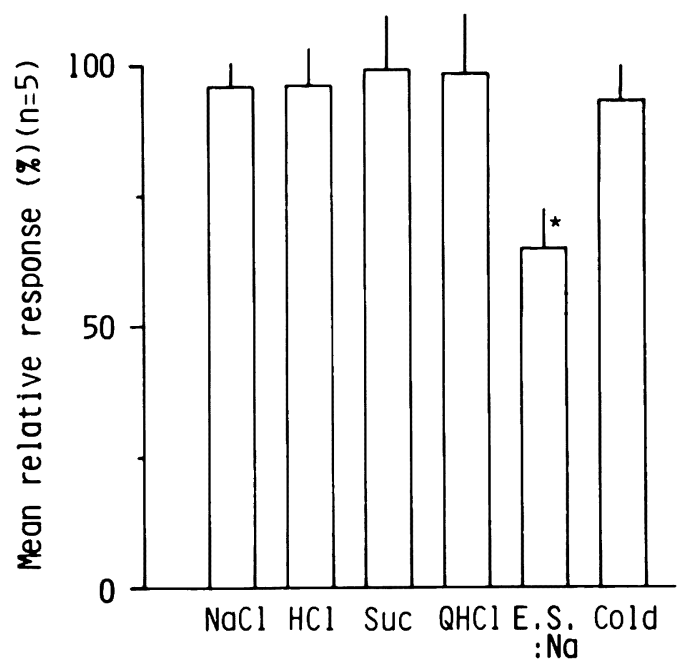

Fig. 9 Mean percent responses (control=100\%) of the chorda tympani nerve to chemical, electrical and cold stimulations after the TTX treatment for $10 \mathrm{~min}$. Vertical bars indicate SDs.

$\star$ : t-test, $\mathrm{p}<0.05$.

効果は制激に用いるメディウムによって異なり， $\mathrm{NaCl}>\mathrm{KCl}>\mathrm{CaCl}>\mathrm{HCl}$ の順であり（Fig. 10）， プロカイン乱処理の場合と全く等しいことが分か 


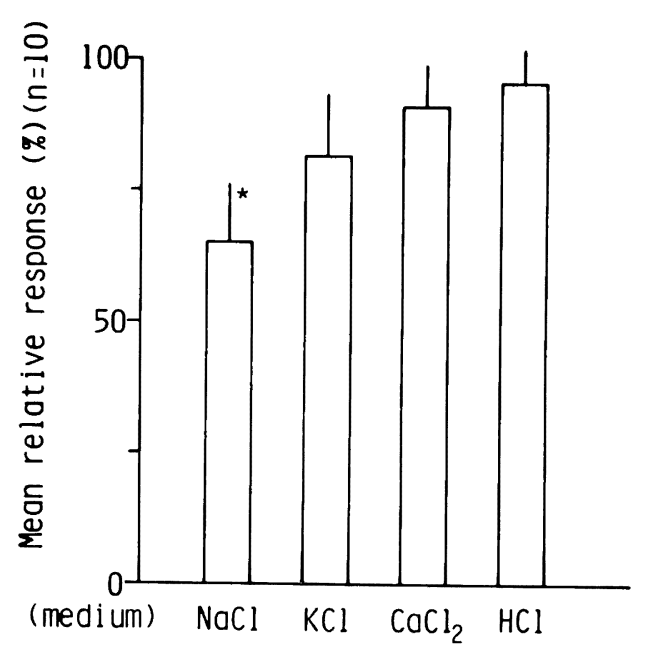

Fig. 10 Mean percent responses (control $=100 \%$ ) of the chorda tympani nerve to anodal stimulations with $0.001 \mathrm{M} \mathrm{NaCl}$ at 15 $\mu \mathrm{A}$ in the bathing medium after the lingual treatment of the TTX for 10 min. Vertical bars indicate SDs. $\star$ : t-test, $\mathrm{p}<0.05$.
った。TTX による応答抑制効果は, 用いた電気 刺激強度2.5 30 $\mu \mathrm{A}$ のすべての範囲にわたって おこり，化学刺激に用いた $\mathrm{NaCl}$ に対する応答 は0.001 1.0Mの浱度範囲で抑制効果が認められ なかった (Fig. 11)。

IV. 単一鼓索神経線維の応答の解析（アミロラ イド，TTX 舌処理による応答抑制効果)

鼓索神経全線維の積分応答の解析から, 電気刺 激に対する受容メカニズムは化学刺激の受容メカ ニズムと共通するアミロライド感受性の受動的 $\mathrm{Na}^{+}$チャネルを介するもの，電気刺激に特異的な TTX の膜電位依存性 $\mathrm{Na}^{+}$チャネルを介するも の, そしてそれ以外のメカニズムの少なくとも 3 種のメカニズムが関与することが明らかとなっ た。しかし，鼓索神経全線維束からの記録では， 化学刺激に対する応答と電気刺激に対する応答が 同一の神経線維上で起こったものかどうか明らか ではない。化学刺激と電気刺激に対する応答が, それぞれ全く異なる神経線維で起こっているので あれば受容メカニズムも全く異なっていることが 考えられる。そこでその点を明らかにするため, 化学・電気両種刺激に対する単一鼓索神経線維の

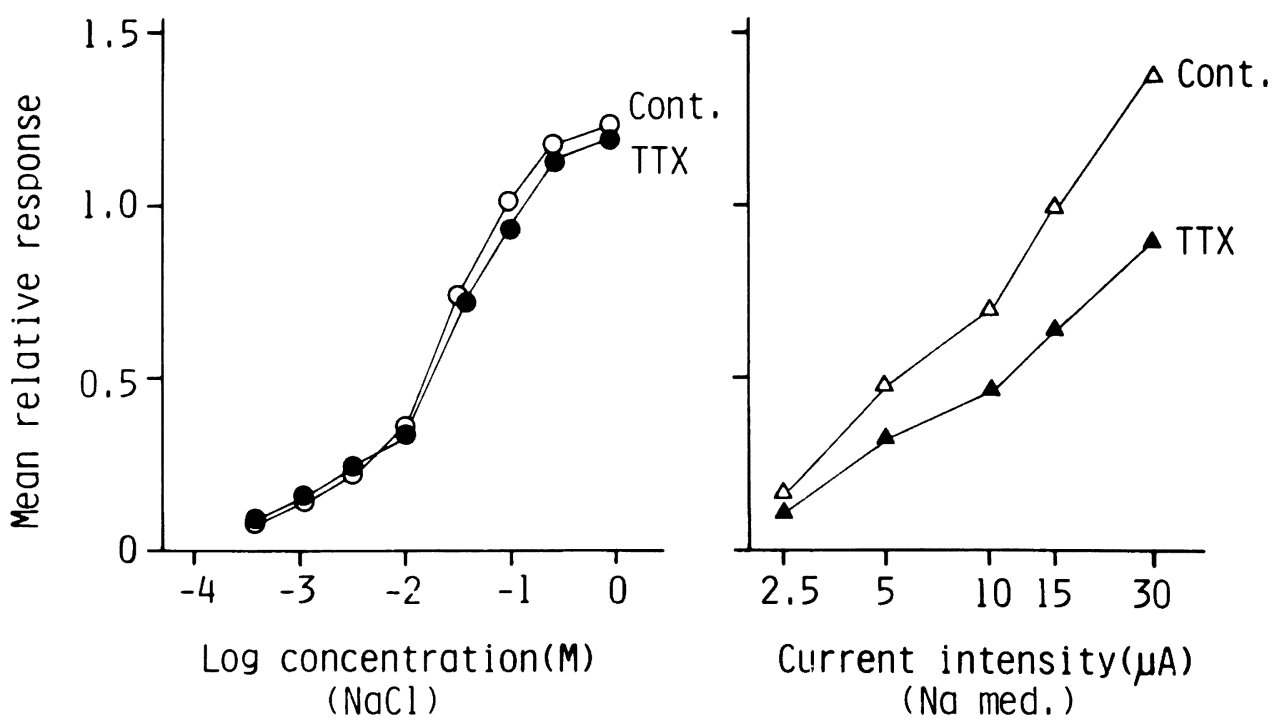

Fig. 11 Concentration-response relationship for $\mathrm{NaCl}$ when the response magnitude for $0.1 \mathrm{M}$ was taken as unity $(1.0)($ left) and intensity-response relationship for the anodal current stimulation with $0.001 \mathrm{M} \mathrm{NaCl}$ in the bathing medium when the response magnitude for $15 \mu \mathrm{A}$ was taken as unity (1.0) (right) before (open symboles) and after (closed symboles) the lingual treatment of the TTX for $10 \mathrm{~min}$. 

IIX
Am!
$(C, S$,
$10 \mathrm{mln}$.
$2 \min$.
$\nabla \quad \nabla$

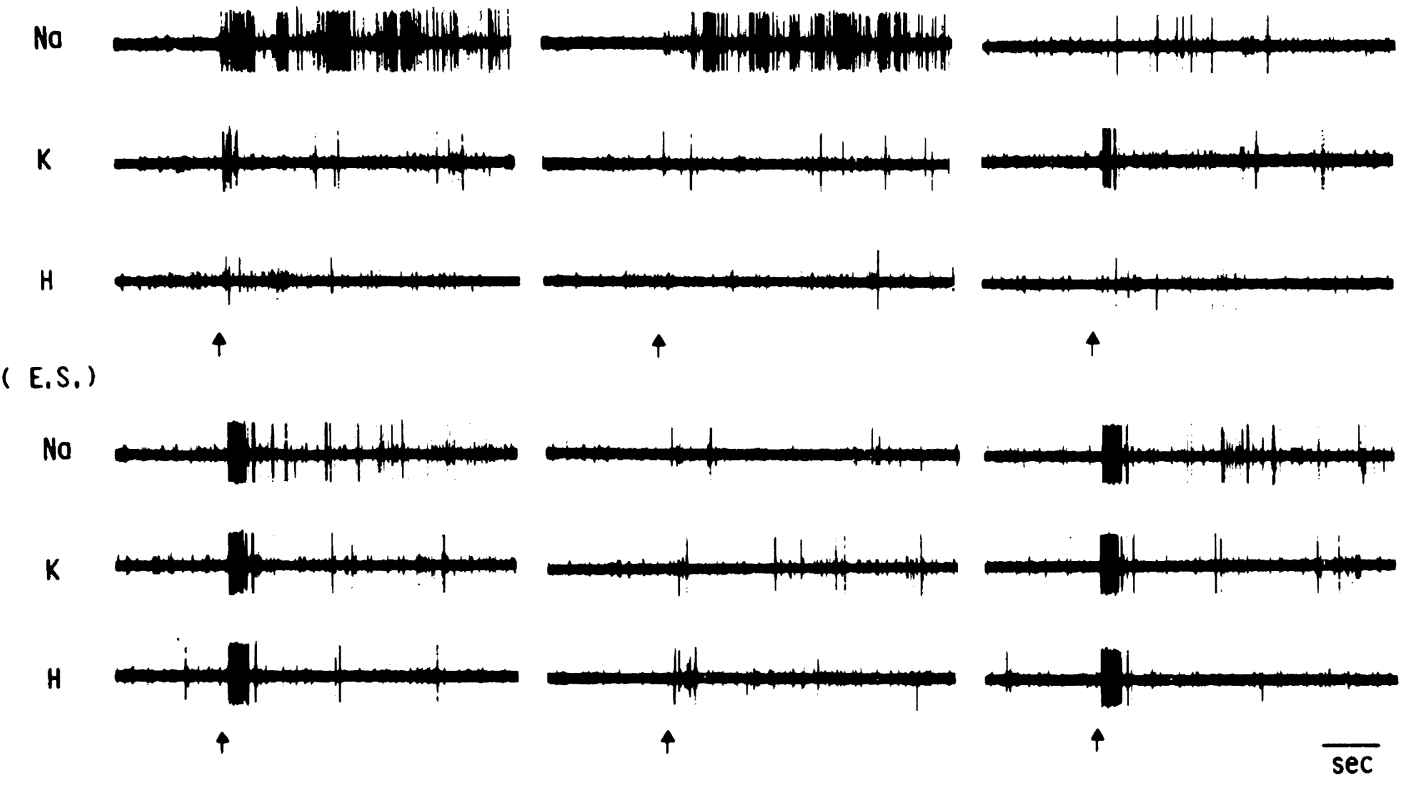

Fig. 12 Left : Single fiber responses of a rat to chemical tongue stimulations (C. S.) with $0.1 \mathrm{M} \mathrm{NaCl}$ $(\mathrm{Na}), 0.1 \mathrm{M} \mathrm{KCl}(\mathrm{K}), 0.01 \mathrm{M} \mathrm{HCl}(\mathrm{H})$ and electrical stimulations (E. S. : $15 \mu \mathrm{A})$ with $0.001 \mathrm{M}$ $\mathrm{NaCl}(\mathrm{Na}), 0.001 \mathrm{M} \mathrm{KCL}(\mathrm{K}), 0.0001 \mathrm{M} \mathrm{HCl}(\mathrm{H})$ in the bath:ng medium before (control) and after (TTX) the treatment of TTX applied to the tongue for $10 \mathrm{~min}$.

Right: Responses of the same fiber to the same chemical and electrical stimulations after the treatment of amiloride to the tongue for $2 \mathrm{~min}$, which were obtained after the recovery from the TTX treatment.

応答のアミロライド， TTX 舌処理による抑制効 果について検討した。

Fig. 12はサンプルした32本の単一鼓索神経線 維のうち 1 本の応答記録例を示す。この線維は, 化学刺激では $\mathrm{NaCl}$ によく応答し, $\mathrm{KCl}, \mathrm{HCl}$ に 対してはわすかかな応答を示すが,電気刺激では $\mathrm{K}$,

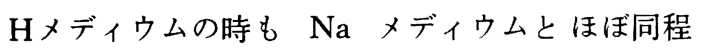
度の応答を示し，化学刺激に対する応答で見られ たような顕著なイオン特異性はないことが分か る。TTX 10分間舌処理後, 化学刺激に対する応 答には変化が見られないが，電気刺激に対する応

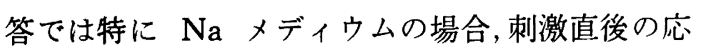
答が顕著に抑制されている。応答回復後, 次にア ミロライドで 2 分間舌処理すると電気刺激に対す る応答は変化なく，化学刺激の $\mathrm{NaCl}$ に対する 応答が抑制された。この例ではアミロライドによ
る応答の抑制効果が化学刺激と電気刺激で明らか に異なっており，鼓索神経全線維束の積分応答で は見い出さ机なかった新たなメカニズムの存在が 示唆された。すなわち, アミロライド感受性メカ ニズムは，化学・電気両種刺激に対する応答を共 に抑制するものと，化学刺激に対する応答だけを 抑制するものとの少なくとも 2 種存在するものと 思われる。

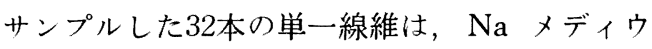
ムの電気刺激に対する応答がアミロライドによっ てのみ抑制された（刺激後 5 秒間のインパルス数 の有意の減少: t-test, $\mathrm{p}<0.05)$ もが10本, TTX によってのみ抑制されたものが 10本，アミロライ ドと TTX 其に抑制されたものが 2 本, アミロラ イドと TTX のどちらにも抑制されなかったもの が10本であった。従って, アミロライドで抑制さ 
E.S.

C.S.

Percent response ( control $=100$ )

$(n=32)$

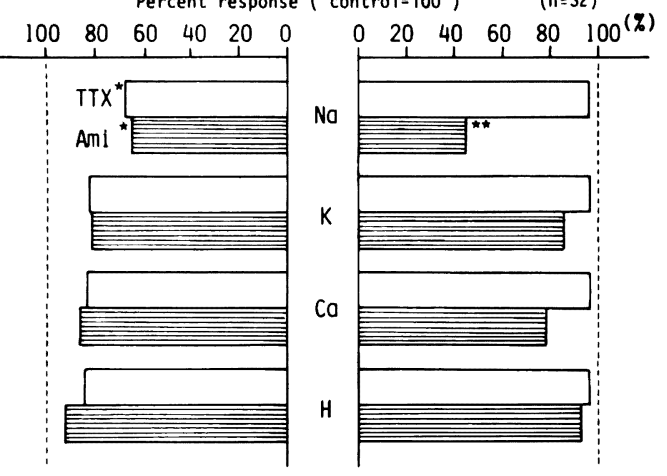

Fig. 13 Mean percent responses (control=100) of 32 single chorda tympani fibers to chemical stimulations (C. S.) with $0.1 \mathrm{M}$ $\mathrm{NaCl}(\mathrm{Na}), 0.1 \mathrm{M} \mathrm{KCl}(\mathrm{K}), 0.1 \mathrm{M} \mathrm{CaCl}_{2}$ (Ca), $0.0001 \mathrm{M} \mathrm{HCl}(\mathrm{H})$ and electrical stimulations (E.S. : $15 \mu \mathrm{A})$ with $0.001 \mathrm{M}$ $\mathrm{NaCl}(\mathrm{Na}), 0.001 \mathrm{M} \mathrm{KCl}(\mathrm{K}), 0.001 \mathrm{M}$ $\mathrm{CaCl}_{2}(\mathrm{Ca}), 0.0001 \mathrm{M} \mathrm{HCl}(\mathrm{H})$ in the bathing medium after the lingual treatment of the TTX (open columns) for $10 \mathrm{~min}$ and the amiloride (striped columns) for $2 \mathrm{~min} . \star$ : t-test, $\mathrm{p}<0.05, \star \star$ : $\mathrm{p}<0.01$.

れた（アミロライド感受性）線維，TTX で抑制さ れた（TTX 感受性）線維はオーバラップしてい るものを加えると共に12本ゔつであった。化学刺 激の $\mathrm{NaCl}$ に対する応答は TTX では抑制され ず，32本のうち16本はアミロライドによって抑制 されたが，そのうち4本は Fig. 12の例にみられ

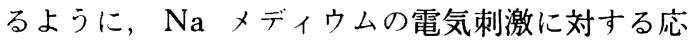
答がアミロライドによって抑制されなかった。

Fig. 13は TTX 及びアミロライドの応答抑制 効果のイオン選択性について示したものである。 単一線維32本の各種刺激に対する薬物処理前の平 均応答頻度を 100 とした時の処理後の平均スパイ ク数を\%で示した。アミロライド舌処理では化学 刺激の $\mathrm{Na}$ 応答がコントロールの約 $45 \%$ (t-test, $\mathrm{p}<0.01)$ ，電気刺激の $\mathrm{Na}$ メディウムの応答は 約 $65 \% （ \mathrm{t}$-test， $\mathrm{p}<0.05 ）$ で有意に減少を示し， 他のイオン種の応答の減少は有意ではなかった。 TTX 舌処理の場合は電気刺激の $\mathrm{Na}$ メディウ ムの応答のみが有意に減少し, 化学刺激に対する 応答には変化がなかった。このようにこれら 2 種
Ami-sensitive units

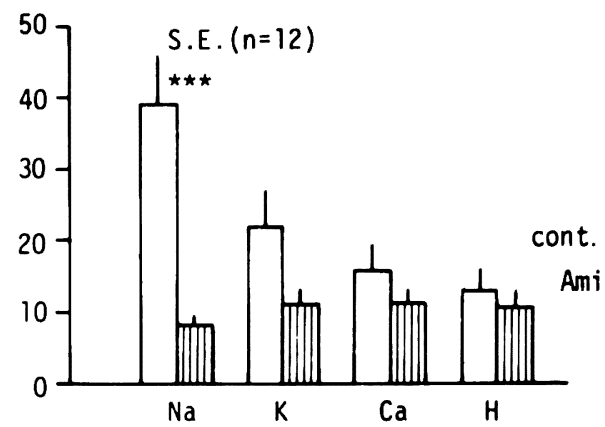

TTX-sensitive units

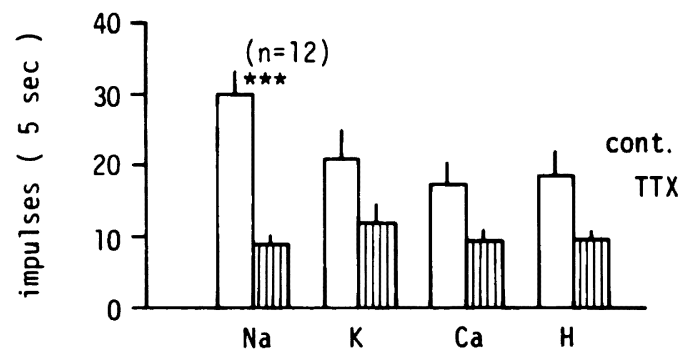

Fig. 14 Mean numbers of impulses for $5 \mathrm{sec}$ of 12 amiloride-sensitive and 12 TTXsensitive single chorda tympani fibers of rats to anodal current stimulations with $0.001 \mathrm{M} \mathrm{NaCl}(\mathrm{Na}), 0.001 \mathrm{M}(\mathrm{KCl}(\mathrm{K})$, $0.001 \mathrm{M} \mathrm{CaCl}_{2}(\mathrm{Ca}), 0.001 \mathrm{M} \mathrm{HCl}(\mathrm{H})$ in the bathing medium before (open columns) and after (striped columns) the lingual treatment of the amiloride for $2 \mathrm{~min}$ and the TTX for $10 \mathrm{~min}$. Vertical bars indicate SDs.

$\star \star \star:$ t-test, $\mathrm{p}<0.001$.

の薬物のいずれも $\mathrm{Na}$ イオンに対する選択性があ ることが分り, 鼓索神経全線維束の 積分応答の解 析とほぼ一致していた。

Fig. 14は電気刺激の $\mathrm{Na}$ メディウムの応答が アミロライド，TTX のそれぞれに抑制された各 12本の神経線維の各メディウムを用いた電気刺激 に対する平均スパイク数をみたものであるが，ア

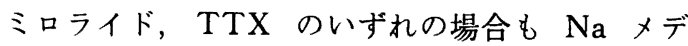
ィウムの応答だけに有意の減少が認められた（ttest, $\mathrm{p}<0.001)$ 。

次に 32 本の単一鼓索神経線維の応答プロファイ ルについて調べた。Fig. 15は薬物処理前の4種の 化学刺激 (コラム) 及び 4 種のメディウムの電気 
No

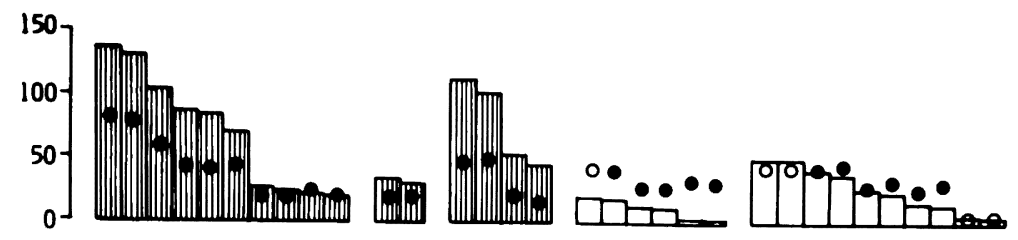

K

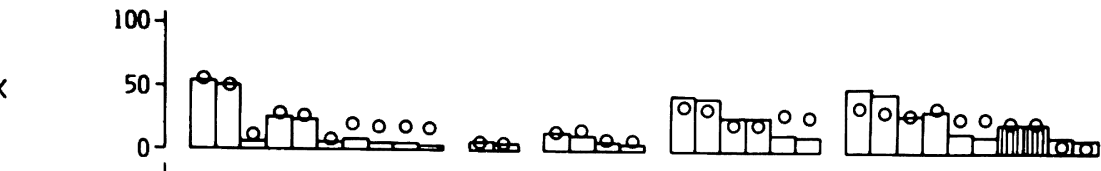

Co

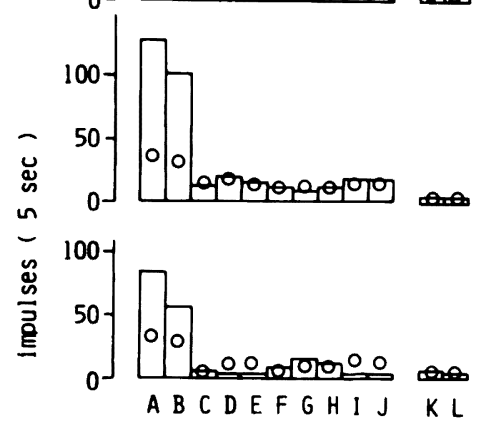

rese

$M N O P$

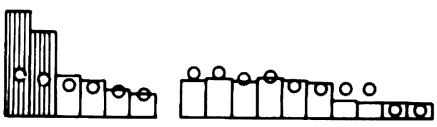

H

E.S. response

Aml-sensitive

TTX-sensitive

\section{C.S. response}

Aml-sensitive

Fig. 15 Response profile (numbers of impulses for $5 \mathrm{sec}$ ) of 32 single chorda tympani fibers (A-f) of rats to the chemical stimulations with $0.1 \mathrm{M} \mathrm{NaCl}, 0.1 \mathrm{M} \mathrm{KCl}, 0.1 \mathrm{M} \mathrm{CaCl}_{2}, 0.01 \mathrm{M} \mathrm{HCl}$ (columns) and the electrical stimulations with $0.001 \mathrm{M} \mathrm{NaCl}, 0.001 \mathrm{M} \mathrm{KCl}, 0.001 \mathrm{M} \mathrm{CaCl}_{2}$, $0.0001 \mathrm{M} \mathrm{HCl}$ in the bathing medium (circles) before the drug's treatment.

Each striped column or filled circle indicates the maximum responses for each fiber to chemical or electrical stimulation. Twelve chorda tympani fibers (A.L) showed suppression of their responses to electrical stimulations with $\mathrm{NaCl}$ by the amiloride treatment (a filled bar). Twelve chorda tympani fibers (K-V) showed suppression of their responses to electrical stimulations with $\mathrm{NaCl}$ by the TTX treatment (a dotted bar). Sixteen chorda tympani fibers (A-P) showed suppression of their responses to chemical stimulations with $\mathrm{NaCl}$ by the amiloride treatment (an open bar).

刺激（丸）に対する刺激後 5 秒間のインパルス数 を示す。縦線のコラム, 黒丸はそれぞれ 4 種のう ちの最大応答值を表す。 $\mathrm{A} \sim \mathrm{L}$ の 12 本の線維 は $\mathrm{Na}$ メディウムの電気刺激に対する応答がアミロ ライドによって抑制されたもので, 化学刺激, 電 気刺激ともに $\mathrm{NaCl}$ 高感受性である。 $\mathrm{K} \sim \mathrm{V}$ の

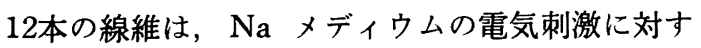
る応答が TTX によって抑制されたものである が，その化学・電気両種刺激に対する応答特性は 均一ではない。 $\mathrm{W} \sim \mathrm{f}$ の 10本の線維は, 電気刺激 に対する応答がアミロライド，TTX で抑制され なかったものである。これらの線維はいずれも，
化学刺激の $\mathrm{HCl}$ に対して高い感受性をもつが, 電気刺激に対する応答はほとんどのイオン種でほ ぼ同じ大きさであり，イオン非特異的な応答を示 す特徵をもっていた。A〜 Pの16本が, 化学刺激 の $\mathrm{NaCl}$ に対する応答がアミロライドによって 抑制された線維であるが，いずれも $\mathrm{NaCl}$ 高感 受性である。 M P P 4 本が，アミロライドによ る抑制が化学刺激の $\mathrm{Na}$ 応答だけにあらわれた 線維であるが，これらはいずれも電気刺激の $\mathrm{Na}$ メディウムの応答が TTX で抑制されたものであ った。

Fig. 16は，化学刺激と電気刺激のイオン特性 

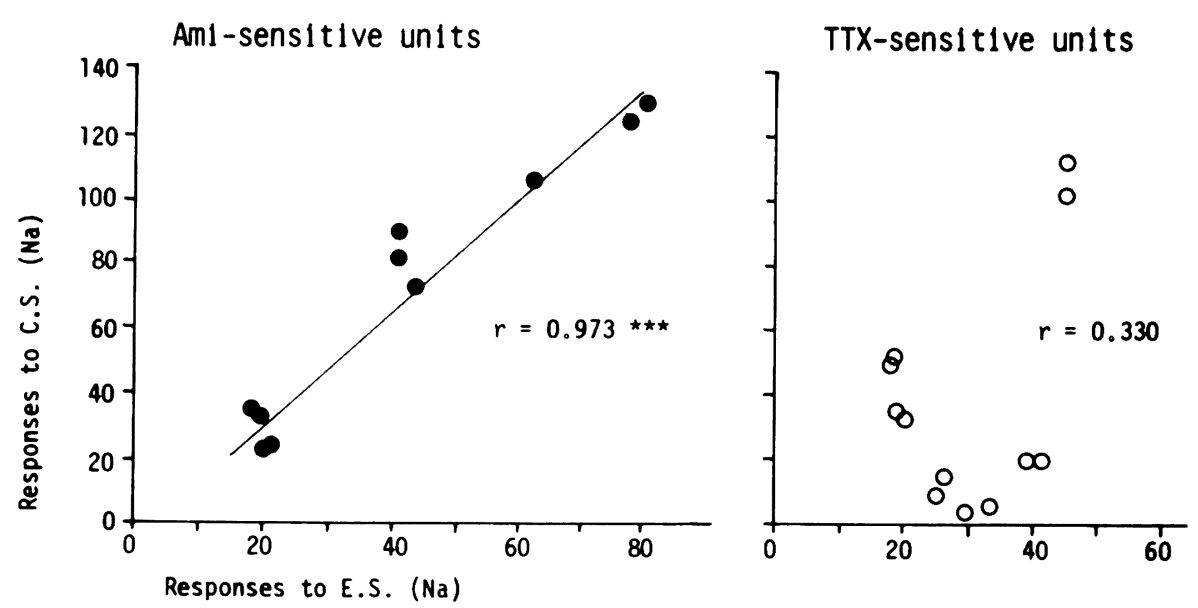

Fig. 16 Correlation between responses to chemical stimulations with $\mathrm{NaCl}$ and electrical stimulations with $\mathrm{NaCl}$ in bathing medium in 12 amiloride-sensitive single chorda tympani fibers (left) and those in 12 TTX-sensitive fibers (right). r: Peason-product moment correlation coefficients. Significant level of correlation coefficients. $\star \star \star: p<0.001$.

について見たものであるが，アミロライド感受性

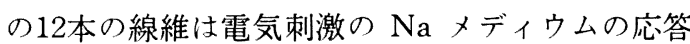
と化学刺激の $\mathrm{NaCl}$ 応答の大きさが相関している $(r=0.973, \quad p<0.001) の に$ 対し，TTX 感受性 の線維では両者は全く相関していないことが分か った $(\mathrm{r}=0.330, \mathrm{p}<0.05)$ 。

\section{考察}

A. アミロライド感受性メカニズムの関与

利尿剂として用いら机るアミロライドは，種々 の上皮細胞の受動的 $\mathrm{Na}^{+}$輸送を阻害する薬物と して知られている16-19!。

近年, DeSimone のグループ18,19,30,31)によって この薬物が，イヌ，ラットの舌上皮の高張 $\mathrm{NaCl}$ 溶液に対するショートサーキットカレントを抑制 し，またラット鼓索神経の $\mathrm{NaCl}$ に対する応答 を選択的に抑制することなどが報告され，塩味の 発現機序にアミロライド感受性 $\mathrm{Na}^{+}$チャネル が関与している可能性が示唆された。ついで Sch ffman ら ${ }^{32}$ によって, ヒトの舌をアミロライドで 処理すると塩味の発現機序が抑制されることが確 認され, その後, ラット ${ }^{31)}$, ジャービル ${ }^{33)}$, 八厶 スター ${ }^{34}$ の鼓索神経で, アミロライドが $\mathrm{NaCl}$ 応 答を選択的に抑制することが明らかとされた。し かし，マドパピー ${ }^{35)}$ では抑制効果自体がみられな
く, カエル 36)では $\mathrm{Na}$ 特異的な抑制効果がない と報告されている。

本実験では，ラットの舌をアミロライドで処理 すると, 鼓索神経の陽極刺激に対する応答が抑制 されることが明らかとなった。化学刺激に対する 応答の抑制効果も $\mathrm{KCl}$ に比べて, $0.03 \sim 0.3 \mathrm{M}$ の範囲で $\mathrm{NaCl}$ に特異的であり, 陽極刺激の場

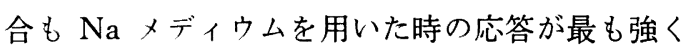
抑制された。この結果は, アミロライド感受性メ カニズムが, 化学・電気両種刺激に対する応答の 発現メカニズムに共通して少なくとも一部関与し ていることを示唆しており，そのメカニズムは， 受動的 $\mathrm{Na}^{+}$チャネルを介するものであると思わ れる。しかし, 単一鼓索神経線維の応答の抑制効 果を解析すると，アミロライドによって化学刺激 の $\mathrm{NaCl}$ の応答は抑制されるが， $\mathrm{NaCl}$ をメ ディウムとした陽極刺激の応答が抑制されない線 維が存在することが明らかとなり，化学刺激の $\mathrm{NaCl}$ の応答のみを抑制する他のアミロライド感 受性メカニズムの存在が示唆された。

Nakamura \& Kurihara ${ }^{37)}$ は，ラットの舌の アミロライド処理による鼓索神経の $\mathrm{NaCl}$ 応答の 変化を, 温度応答特性の関係から調べ, アミロラ イド感受性メカニズムが 2 種存在することを見い だし，それらは， $\mathrm{NaCl}$ に対する応答間值から味 
受容膜を境にしての $\mathrm{Na}^{+}$の平衡電位がー $30 \mathrm{mV}$ と $-85 \mathrm{mV}$ 付近になると思われる 2 種の $\mathrm{NaCl}$ 応 答のコンポーネントのそれぞれに影響を与えるだ ろうことを報告している。ラット味細胞の静止電 位はー30〜 - $50 \mathrm{mV}$ である ${ }^{38,391}$ とすれば，前者の コンポーネントに関与するアミロライド感受性メ カニズムは, $\mathrm{Na}^{+}$イオンの受動的移動に関倸する と考えることができるが（脱分極応答を示すの で), 後者のコンポーネントに関与するアミロライ ド感受性メカニズムは, 受容膜を介する $\mathrm{Na}$ イオ ンの移動には無関係のもので，おそらく受容膜の $\mathrm{Na}$ 受容サイトに何らかの影響を与えるものであ ることが考えられる。本実験結果の示す， 2 種の アミロライド感受性メカニズムもそれによく対応 している。

B. プロカイン感受性メカニズムの関与

局所麻酔薬は, 一般に細胞の膜電位依存性 $\mathrm{Na}^{+}$ チャネルの阻害剤として働くことが知られてい る $^{26-29)}$ が, ヒトの舌表面に与えると, 痛覚, 苦味,

塩味, 酸味, 触覚の順に感覚が消失寸ることが報 告されている ${ }^{21}$ 。また，カエルの味細胞において も，プロカイン舌処理によって塩酸キニーネに対 する応答の方が, $\mathrm{HCl}$ に対する応答よりも顕著に 抑制されることが報告されている ${ }^{231}$ 。本実験では， ラットの舌のプロカイン10分間処理によって，陽 極刺激に対する鼓索神経応答が抑制され，他に化 学刺激（4 基本味溶液）に対する応答は抑制され ないことが明らかとなった。しかし，このプロカ インによる抑制効果は，用いるプロカインの濃度 と処理時間によって変化し，1\%プロカイン30分 間舌処理においては，陽極刺激に対する応答のみ ならず, $0.1 \mathrm{M} \mathrm{NaCl}, 0.02 \mathrm{M}$ 塩酸キニーネ, 冷 刺激に対する応答も抑制された。局所麻酔剂の作 用機序として, 細胞脂質膜を介して細胞内に入り, 内側から $\mathrm{Na}^{+}$チャネルを阻害することが考えら れていること年-29) から， プロカインが味細胞内に 流入すれば，受容膜側のみならず，シナプス部位 の膜周辺にも影響を与える可能性もある。従っ て, さらに濃度, 処理時間を増加させれば, いず れはすべての刺激に対する応答も抑制されるもの と考えられる。Ozeki \& Noma ${ }^{22)}$ は, ラットの 舌に $0.5 \%$ プロカインを 30 分間処理すると, $\mathrm{NaCl}$
や塩酸キニーネに対する応答は抑制されず, $\mathrm{HCl}$ に対する応答が抑制され，シュクロースに対する 応答は逆に増強されるとのべており，本実験結果 とは相反する結果を示している。しかし，彼らの 報告では例数は示されておらず, 統計学的検索も 行われていないため，本実験結果比較することは 難しい。Tateda \& Beidler ${ }^{15)}$ はラットの舌を $1.0 \%$ コカインで 1 分間処理すると, 各種浱度の $\mathrm{NaCl}$ に対する味細胞膜電位が脱分極応答から過 分極応答に変化することを示している。

また本実験結果は，陽極刺激に用いた 4 種のメ

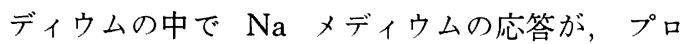
カイン処理後最も顕著に抑制されており，プロカ インの効果は, 特定の処理条件下で $\mathrm{Na}^{+}$イオン に特異的である。しかし，化学刺激の $\mathrm{NaCl}$ 応 答は変化がないことから，プロカイン感受性のメ カニズムを介する系は, 電気味覚の発現に特異的 であり，化学性味覚の発現機序には全く含まれな いものであることが示唆された。

C. TTX 感受性メカニズムの関与

TTX は局所麻酔薬と同様に膜電位依存性の $\mathrm{Na}^{+}$チャネル阻害例であるが，その阻害効果のイ オン特異性は, 局所麻醉薬よりも著しく高いこと が知られている。

本実験では, 電気性味覚の発現に関与するプロ カイン感受性メカンズムが, 膜電位依存性 $\mathrm{Na}^{+}$チ ヤネルを介寸るものであるかを確かめるため, TTX 舌処理によるラット鼓索神経応答の変化に ついて調べた。その結果, TTX 舌処理は, 化学 刺激に対する応答は変化せず，陽極刺激に対する 応答だけを抑制した。しかも TTX は，陽極刺 激に用いた 4 種のメディウムの中で $\mathrm{Na}$ メディ ウムの応答を最も顕著に抑制し，プロカイン舌処 理の場合とほぼ同様の $\mathrm{Na}^{+}$イオン特異性を示す ことがわかった。また, 単一鼓索神経線維の応答 を調べると，TTX で陽極刺激の応答が抑制され る線維は，全体の約38\%（12/32本)であり，しか もそれらの線維の応答性は, 化学刺激の $\mathrm{NaCl}$ に 対する応答性と全く無関係であり, 各神経線維の 電気刺激に対する応答だけを抑制することがわか った。TTX 舌処理によっても化学刺激の応答が 変化しないということは，TTX が神経線維に直 
接働いたのではなく，味細胞に働いたことを示し ている。しかも TTX 舌処理後，舌洗浄を開始 し約15分後には陽極刺激の応答がほぼ元のレベル に回復することや，TTX による抑制効果がイオ ン特異的であることを考えると，TTX の作用受 容膜側（タイトジャンクションよりも上側）にあ る可能性が高い。Ozeki \& Noma ${ }^{221}$ は，カエル の舌を TTX で処理すると，味細胞の味刺激に 対する脱分極応答は変化しないが，舌咽神経の味 応答は抑制されるとし，TTX は神経に直接作用 することが考えられると述べている。この結果は， ラットにおける本実験結果とは異なっている。し かし，本実験における TTX 舌処理条件では,化 学刺激に対する応答は抑制されないことから，舌 咽神経の味応答が抑制される Ozeki \& Noma の カエルの例とは処理効果が異なり，味蕾周辺の構 造上の種差などから同一処理時間でもラットの方 がカエルよりも薬物が味覚器に作用し難くなって いる可能性が考えられる。TTX 感受性メカニズ 厶, 寸なわち膜電位依存性 $\mathrm{Na}^{+}$チャネルが存在 することは, 最近, カエル20,40) マッドパピー41)で 報告されている。カエルの場合は，味細胞内に与 えた陰極刺激の off 応答として，マッドパピー の場合は単離味細胞の細胞内に陽極刺激を与えた 時の応答として，いずれも活動電位が発生し，そ の電位は TTX 舌処理によって抑制された。この TTX 感受性 $\mathrm{Na}^{+}$チャネルの存在部位について は最近 apical と basolateral の両部分に存在す るという報告がある ${ }^{42,43)}$ 。

D. アミロライドおよび TTX 抵抗性メカニズ 么の関与

ラット鼓索神経全線維束の陽極刺激に対する応 答は，アミロライド，プロカインあるいは TTX 舌処理によって完全に消失するわけではなく， ア ミロライドでコントロールの $70 \%$ ，プロカインで $40 \sim 60 \%$, TTX で約 $65 \%$ まで応答の減少が認め られたにすぎない。プロカインと TTX の関与 するメカニズムは，先に述べたように，共に膜電 位依存性 $\mathrm{Na}^{+}$チャンネルを介するもので共通す るとすれば，陽極刺激に対する応答の発現機序に は，アミロライド，TTX 感受性メカニズムの両 メカニズム以外の第 3 のメカズムの関与を考え
なければ応答全体を説明することは出来ない。そ こで, 本実験ではさらに単一鼓索神経線維の応答 を調べたところ約30\%(10/32本) の線維において， アミロライド，TTX 舌処理によっても陽極刺激 の応答が変化しないことがわかり，これらの線維 の陽極刺激の応答発現には，アミロライド，TTX 抵抗性の第 3 のメカニズムが関与していることが 示唆された。この10本の線維は, 化学刺激に対し ては $\mathrm{HCl}$ に高感受性の特徵があり, 他の塩類に 対して応答を示し，電解質味刺激に広い感受性を 有しており，また陽極刺激においてはメディウム による応答性が極めて少なく，イオン非特異的な 态答特性を持っていた。このメカニズムが，電気 性味覚に特異的なものであるか， あるいはその味 細胞における存在部位は受容膜側であるのかシナ プス膜側であるのか，現時点では全く不明である。 提唱されている電気性味覚の成因の 3 つの仮説の うちの1つである “味細胞のシナプス部位に電流 が流れ込みシナプス伝達を起こす” という考え方 は，このイオン非特異的な応答特性を矛盾なく説 明する。しかし，その際に味細胞膜に流れると思 われる電流を運ぶイオン種は，刺激に用いたメデ ィウム以外のものなのか, そのイオンはどのチャ ネルを通るものなのか，といった点が新たな疑問 となる。最近, Kinnamon \& Roper ${ }^{44}$ はマッド パピーの単離味細胞の応答を調べ, $\mathrm{KCl}$ あるいは 酸刺激による脱分極応答は受容膜側にある膜電位 依存性の $\mathrm{K}^{+}$チャネルのコンダクタンスを減少さ せることによってもたらされると報告している。 もしこの膜電位依存性 $\mathrm{K}^{+}$チャネルが, ラットの 味細胞にも存在するのであれば，そのコンダクタ ンスの減少は陽極刺激にもメディウム非特異的に 起こりうるが, 通常, 陽極刺激の際に誘発される 酸味の発現とも関連する可能性がある。この $\mathrm{K}^{+}$チ ヤネルの存在の有無, あるいはその電気性味覚発 現への関与については, 今後さらに検討する必要 がある。

Bujas ら ${ }^{12}$ は，ヒトの舌に種々のメディウムの 陽極刺激を行い，誘発される味覚を調べたところ， メディウムの種類に関係なく誘発された味は酸味 であったと報告している。また，陽極刺激と電解 質溶液との交叉順応効果を調べると，舌に $\mathrm{NaCl}$ 
を与えたあとに最も大きな順応効果が生じると述 べている。本実験結果から, 陽極電気刺激の応答 発現にアミロライド感受性, TTX 感受性の $\mathrm{Na}^{+}$ チャネルだけでなく第 3 の $\mathrm{Na}^{+}$イオン非特異的な 特徵をもつメカニズムも関与しており, 電気刺激 で誘発される味覚が化学刺激の場合と異なる可能 性も充分考えられる。

Ninomiya \& Funakoshi ${ }^{45)}$ は, ラットの単一 鼓索神経線維の電気刺激に対する応答性は多様で あり，陽極刺激にだけ応答を示すもの（Type A 線維), 陽極, 陰極刺激共に応答を示すもの（Type B線維), 陰極刺激だけに応答を示すもの (Type C線維）が存在することを報告している。本実 験においても, アミロライド感受性, TTX 感受 性の線維, アミロライド, TTX 抵抗性の線維が 存在することが明らかとなり，それぞれの線維の 支配する味細胞には上記のメカニズムが不均一に 存在し, 味細胞固有の電気的性質をもたらし, 化 学刺激に対する応答性と電気刺激に対する応答性 が必ずしも一致しない結果となっていることが考 えられる。したがって, 電気性味覚の発現には, 少なくとも 3 種の異なるメカニズムが関与してお り, 舌上のイオン種が化学刺激の場合と同じであ っても, 電気刺激により化学刺激の場合よりも多 くの神経線維がより非特異的に応答する可能性が 高い。ある程度特異的な線維の興奮を伴う化学性 味覚の場合とは異なって, 電気性味覚は非特異的 な線維の興奮によって誘発されているものと思わ れる。

\section{結 論}

ラット鼓索神経の化学・電気両種刺激に対する 味覚応答の,アミロライド, プロカイン, TTX な
ど $\mathrm{Na}^{+}$チャネル阻害剂舌処理による抑制につい て検討し, 以下のような結果を得た。

(1) 受動的 $\mathrm{Na}^{+}$輸送を抑制するアミロライド 舌処理により, $\mathrm{NaCl}$ 溶液による化学刺激と $\mathrm{Na}$ メディウムの電気刺激に対する 鼓索神経束の応答 が抑制された。

(2) 単一鼓索神経線維には, アミロライド舌処 理により化学刺激と電気刺激に対する応答が，と もに抑制されるもの，化学刺激に対する応答だけ が抑制されるもの，応答に全く変化が認められな いものとが存在した。

(3) $\mathrm{Na}^{+}$チャネル阻害効果を有する局所麻酔薬 プロカイン舌処理により，電気刺激に対する鼓索 神経束の応答が著明に抑制された。

(4) 膜電位依存性 $\mathrm{Na}^{+}$チャネル阻害剤 TTX 舌処理においても，電気刺激に対する鼓索 神経束の応答だけが選択的に抑制された。

(5) 単一鼓索神経線維には TTX 舌処理によ り電気刺激に対する応答だけが抑制されるもの と, 応答に全く変化が認められないものとが存在 した。

以上の結果より, 電気性味覚の発現には, 化学 性味覚と共通するアミロライド感受性 $\mathrm{Na}^{+}$チャ ネルと, 電気性味覚に特異的な TTX 感受性 $\mathrm{Na}^{+}$ チャネルを介するメカニズムと，アミロライド・ $\mathrm{TTX}$ 抵抗性の少なくとも 3 種のメカニズムが関 与することが明らかとなった。

稿を終わるにあたり, 本研究に終始御懇篤な御指導と 御校閲を賜りました朝日大学歯学部口腔生理学教室船越 正也教授に梁く感謝いたします。また, 本研究の遂行に 終始御指導と御助言を睗りました同教室二, 宮裕三助教 授に心より感謝の意を表します。そして，種々御協力械 いた教室員各位に，心より御礼申し上げます。

抄録 : 電気性味覚の発現機序を明らかにする目的で, ラット鼓索神経の 化学電気両種刺激に対する味覚応 答の， $\mathrm{Na}^{+}$チャネル阻害剤（アミロライド，プロカイン，TTX）舌処理による抑制効果について比較検討

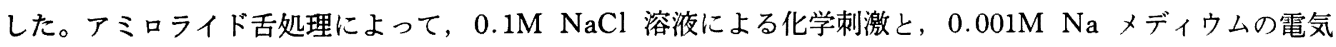
刺激に対する鼓索神経束の応答が， $\mathrm{Na}^{+}$イオン特異的に抑制された。プロカインや TTX による舌処理で む， $0.001 \mathrm{M} \mathrm{Na}$ メデウムの電気刺激に対する応答は抑制された。このようなアミロライドや TTXによ る, $\mathrm{Na}^{+}$イオン特異的あるいは電気刺激特異的な応答抑制は，単一鼓索神経線維のうちそれぞれ約 $30 \sim 50 \%$ 線維においても認められた。これらの結果は, アミロライド感受性 $\mathrm{Na}^{+}$チャネルあるいは TTX 感受性 $\mathrm{Na}^{+}$チャネルを介するメカニズムとそれらの $\mathrm{Na}^{+}$チャネルを介さないメカニズムの3つが, 電気性味覚の 発現機序に関与していることを示唆している。 


\section{文献}

1) Sulzer, M. : Recherches sur lórigine des sentiments agréables et desagréables, Troisiéme partie: Des plasisiro des sens, Historie de l'académie des sciences et belles lettres de Berline, 1752, Quoted form: Bujas, Z. : Electric taste, In: Handbook of Sensory Physiology, 4, Chemical Senses, Pt, 2, Taste, ed by Beidler, L. M., Springer-Verlag, Berlin, pp. 180-199, 1971.

2) Bujas, Z.: Electric taste, In: Handbook of Sensory Physiology, 4, Chemical Senses, Pt. 2, Taste, ed, by Beidler, L. M., SpringerVerlag, Berlin, pp. 180-199, 1971.

3) 三吉康郎, 吉浦襀二、木村知郎, 中根英晴 : 臨 床味覚検查法の1つとして電気性味覚検査法 Krarup 氏法の検討。日耳鼻誌 71:1477-1483, 1968.

4）富田寞, 少名子正楌, 山田 登, 都川紀正 : 電気味覚計 (Elgustometer) - 2, 3 の基礎的問 題一。 日耳異誌 72 : 868-875, 1969.

5）富山紀彦，冨田 寞，奥田雪雄：電気味覚の正 常值. 日耳鼻誌 74: 1580-1587, 1971.

6）冨田 寛：味覚の臨床. 日耳鼻誌 79 : 12671271, 1976.

7) Krarup, B. : Electro-gustometory: a method for clinical taste examinations. Acta Oto-larung. 49 : 294-305, 1958.

8) Smith, D. V. and Bealer, S. L. : Sensitivity of the rat gustatory system to the of stimulus onset. Physiol. Behav. 15 : 303-314, 1975.

9) Ninomiya, Y. and Funakoshi, M.: Role of ions in generation of taste nerve responses to electrical tongue stimulation in rats. Jpn. J. Physiol. 31 : 891-902, 1981

10) Herness, M. S. : Neurophysiological and biophysical evidence on the mechanism of electric taste. J. Gen. Physiol. 86: 59-87, 1985.

11) Kashiwayanagi, M., Yoshii, K., Kubotaka, Y. and Kurihara, K.: Taste transduction mechanism, Similar effects of various modifications of gustatory receptors on neural responses to chemical and electrical stimulation in the frog. J. Gen. Physiol. $78: 259-$ $275,1981$.

12) Bujas, Z., Ajduković, D. and Mayer, D. : Psychophysical investigations of taste effects provoked by simultaneous application of taste solutions and electric current. Acta Biol. 50 : 1-21, 1984.

13) Ninomiya, Y., Mizukoshi, T., Nishikawa, T. and Funakoshi, M.: Ion specificity of rat chorda tympani fibers to chemical and electrical tongue stimulations. Brain Res.,
404 : 350-354, 1987.

14) Ninomiya, Y. and Funakoshi, M.: Amiloride inhibitions of responses of rat single chorda tympani fibers to chemical and electrical tongue stimulations. Brain Res. 451: 319-325, 1988.

15) Tateda, H. and Beidler, L. M.: The receptor potential of the taste cell of the rat. J. Gen. Physiol. 47 : 479-486, 1963.

16) Benos, D. J. : Amiloride : a molecular probe of sodium transport in tissue and cells. Am. J. Physiol. 242 : c 131-c 145, 1982.

17) Biber, T. V. L. : Effect of changes in transepithelial transport on the uptake of sodium across the outer surface of the frog skin. J. Gen. Physiol. 58 : 131-144, 1971.

18) DeSimone, J. A., Heck, G. L. and DeSimone, S. K.: Active ion transport in dog tongue: a possible role in taste. Science 214: 1039-1041, 1981.

19) DeSimone, J. A., Heck, G. L., Mierson, S. and Desimone, S. K. : The active ion transport properties of canine lingual epithlia in vitro. J. Gen. Physiol. 83 : 633-656, 1984.

20) Kashiwayanagi, M., Miyake, M. and Kurihara, K.: Voltage-dependent $\mathrm{Ca}^{2+}$ channel and $\mathrm{Na}^{+}$channel in frog taste cells. Am. J. Physiol. 244 : c82-88, 1983.

21) Moncrief, R. W.: The Chemical senses, 2nd edn., Leonard Hill Ltd., London, p. 159, 1951.

22) Ozeki, M. and Noma, A.: The actions of tetrodotoxin, procaine and acetylcholine on gustatory receptors in frog and rat. Jpn. J. Physiol. 22 : 467-475, 1972.

23) Akaike, N. and Sato, M. : Effects of local anesthetics on frog taste cell response. Jpn. J. Physiol. 25 : 585-597, 1975.

24) Hellekant, G., Aronsson, T. and Carlbom, U. : Taste-o-matic: an advanced device for taste stimulation, In: Olfaction and Taste, vol. 7, ed. by van der Starre, H. IRL Press, London and Washington, p203, 1980.

25) Hellekant, G. : Postexcitatory depression of gustatory receptors. Acta Physiol. Scand. 74 : 1-9, 1968.

26) Deguchi, T. and Narahashi, T. : Effects of procaine on ionic conductances of end-plate membranes. J. Pharmacol, exp. Ther. 176 : 423-433, 1971.

27) Hille, B. : The pH-dependent rate of action of local anesthetics on the node of Ranvier. J. Gen. Physiol. 69 : 475-496, 1977.

28) Hille, B.: Local anesthetics: hydrophilic and hydrophobic pathways for the drug re- 
ceptor reaction. J. Gen. Physiol. 69 : 497515, 1977.

29) Narahashi, T., Anderson, N. C. and Moore, J. Wm: Comparison of tetrodotoxin and procaine in internally perfused squid giant axons. J. Gen. Physiol. 50 : 1413-1428, 1967.

30) DeSimone, J. A. and Ferrell. F : Analysis of amiloride inhibition of chorda tym. pani taste response of rat to $\mathrm{NaCl}$. Am. J. Physiol. 249 : R52-61, 1985.

31) Heck, G. L., Mierson, S. and DeSimone, J. A. : Salt taste transduction occurs through an amiloride-sensitive sodium transport pathway. Sciense 223 : 403-405, 1984.

32) Schiffman, S. S., Lockhead, E. and Maes, F. W.: Amiloride reduces the taste intensity of $\mathrm{Na}^{+}$and $\mathrm{Li}^{+}$salt and sweetness : Proc. Natl. Acad. Sci. USA. 80 : 6136-6140, 1983.

33) Jakinovich, Jr. W.: Stimulation of the gerbil's gustatory receptors by methyl glycopyranosides. Chem. Sens. 10:591-604, 1985.

34) Pfaffmann, C. and Pritchard, T.: Ion specificity of "Electric Taste", In : Olfaction and Taste, vol. 7, ed. by van der Starre, $\mathrm{H}$. IRL Press, London, pp. 175-178, 1980.

35) McPheeters, M. and Roper, S. D. : Amiloride does not block taste transduction in the mudpuppy. Necturus maculosus. Chem. Sens. $10: 341-352,1985$.

36) Yoshii, K., Kiyomoto, Y. and Kurihara, K. : Taste receptor mechanism of salts in frog and rat. Comp. Biochem. Physiol. 85A : 501-507, 1986.

37) Nakamura, M. and Kurihara, K.: Temper- ature dependence of amiloride-sensitive and -insensitive components of rat taste nerve response to $\mathrm{NaCl}$. Brain Res. $444: 159-164$, 1988.

38) Ozeki, M. : Conductance change associated with receptor potentials of gustatory cells in rat. J. Gen. Physiol. 58:688-699, 1971.

39) Sato, T. and Beidler, L. M. : The response characteristics of rat taste cells to four basic taste stimulli. Comp. Biochem. Physiol. 73A : 1-10, 1982.

40) Miyamoto, T., Okada, Y. and Sato, T. : Membrane properties of isolated frog taste cells : three types of responsivity to electrical stimulation. Brain Res. 449 : 369-372, 1988.

41) Roper, S. : Regenerative impulses in taste cells. Science 220 : 1311-1312, 1983.

42) Kinnamon, S. C., Dionne, V. E. and Beam, K. G. : Aaical localization of $\mathrm{K}^{+}$channels in taste cells provides the basis for sour taste transduction. Proc. Natl. Acad. Sci. USA. 85 : 7023-7027, 1988.

43) Roper, S. D. and McBride, D. W. Jr. : Distribution of ion channels on taste cells and its relationship to chemosensory transduction: J. Membrane Biol. 109 : 29-39, 1989.

44) Kinnamon, S. C. and Roper, S. D. : Membrane properties of isolated mudpuppy taste cells: J. Gen. Physiol. 91 : 351-371, 1988.

45) Ninomiya, Y. and Funakoshi, M. : Responces of rat chorda tympani fibers to electrical stimulation of the tongue: Jpn. J. Physiol. 31 : 559-570, 1981. 